\title{
Can pre-feeding of a whey protein affect the glucoregulatory response to an oral glucose tolerance test?
}

\author{
P. Shaw, W. McCormac, B. McCarthy and P. Jakeman \\ Faculty of Education and Health Sciences, University of Limerick, Plassey Technological Park, Limerick, \\ Republic of Ireland
}

The stimulating effect of a co-ingestion of carbohydrate and protein and/or amino acids on endogenous insulin release is well known. To this effect, the co-ingestion of protein with carbohydrate is known to improve glucose homeostasis in patients with type-II diabetes ${ }^{(1)}$. In the absence of carbohydrate, the insulinotropic effect of whey protein induces a rise in plasma insulin and lowering of blood glucose within 30 min of ingestion ${ }^{(2)}$. Pre-feeding protein may, therefore, be a worthwhile strategy to improve postprandial glucoregulatory control.

The present paper reports on the effect of pre-feeding whey protein isolate on subsequent glucose response to an oral glucose load. With ethical approval and informed consent eight healthy young subjects $\left(\hat{\jmath}, n=4\right.$, age $21.8(0.5)$ years, BMI $22.5(3.7) \mathrm{kg} / \mathrm{m}^{2} ;$;,$n=4$, age $23.5(2.4)$ years, BMI $24.3(2.5) \mathrm{kg} / \mathrm{m}^{2}$ ) undertook a randomised control trial of two treatments, either protein solution (whey protein isolate (WPI); $0.3 \mathrm{~g} / \mathrm{kg}, 8 \%(\mathrm{w} / \mathrm{v})$ water) or control (CON; equivalent volume of water), each treatment separated by $7 \mathrm{~d}$. Following an overnight fast subjects were fed either protein or water $30 \mathrm{~min}$ prior to ingestion of glucose $(75 \mathrm{~g} ; 28 \%(\mathrm{w} / \mathrm{v})$ in water; OGTT). Blood glucose was measured prior to feeding and every $15 \mathrm{~min}$ for $2 \mathrm{~h}$ post-glucose ingestion. The area under the curve for blood glucose $\left(\mathrm{AUC} \mathrm{C}_{0-120}\right)$ was calculated by trapezoidal integration. The difference in the mean response was analysed by paired Student's $t$-test.

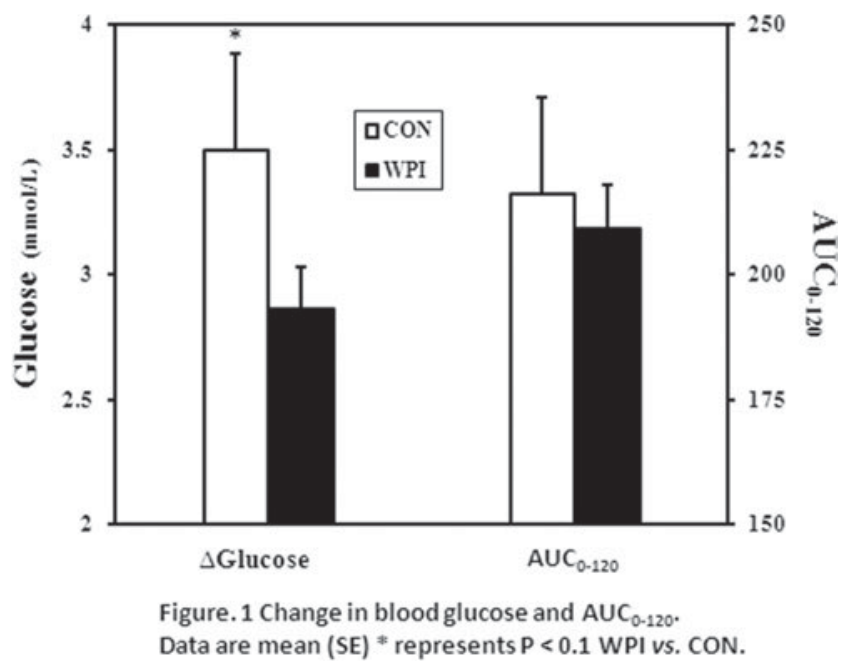

Peak glucose occurred $30 \mathrm{~min}$ following glucose ingestion. Pre-feeding of WPI resulted in $22 \%$ lower mean rise in peak glucose (3.50(0.38) v. 2.86(0.17) $\mathrm{mmol} / \mathrm{l} ; P=0.076)$ and a $7 \%$ lower mean peak blood glucose $(8.25(0.42) \mathrm{v} .7 .66(0.35) \mathrm{mmol} / \mathrm{L} ; P=0.109)$ than in the $\mathrm{CON}$ trial. However, no difference in effect was observed when blood glucose was calculated as the integrated $\mathrm{AUC}_{0-120}$ (216(32) v. 209(26) $\mathrm{mmol} / \mathrm{min} / \mathrm{l} ; P=0.429$; Figure 1 ).

Measured by change in the glucose response to an oral glucose tolerance test, the data from this study show that pre-feeding of approximately $25 \mathrm{~g}$ of a soluble whey protein timed to coincide with the peak rise in protein-induced endogenous insulin secretion produced a modest reduction in the post-ingestion increase and peak blood glucose concentration, but no change in $\mathrm{AUC}_{0-120}$ for blood glucose, in healthy young subjects. As a nutrient intake, the amount of protein used in this study is low. Further study will confirm whether this pre-feeding glucoregulatory effect follows a similar dose-dependent insulinotropic response to whey protein ingestion ${ }^{(3)}$.

1. Manders RJ, Praet SF, Meex RC et al. (2006) Co-ingestion of a protein hydrolysate with or without additional leucine effectively reduces post-prandial blood glucose excursions in Type 2 diabetic men. J Nutr 136, 1294-1299.

2. Power O, Jakeman P \& Hallihan A (2009) Human insulinotropic response to oral ingestion of native and hydrolysed whey protein. Amino Acids 37, 333-339.

3. Claessens M, Saris WHM \& Baak MA (2008) Glucagon and insulin responses after ingestion of different amounts of intact and hydrolysed proteins. Br J Nutr 100, 61-69. 